\title{
Growth, Oxalate and Vitamin C Content of Red Amaranth (Amaranthus tricolor L.) Treated with Salicylic Acid
}

\author{
Chlarissa Bella Asy Shyfa ${ }^{1}$, Kumala Dewi ${ }^{*}$ \\ ${ }^{1}$ Alumni of Faculty of Biology, Universitas Gadjah Mada, Yogyakarta, Indonesia \\ ${ }^{2}$ Plant Physiology Laboratory, Faculty of Biology, Universitas Gadjah Mada, Yogyakarta, Indonesia
}

ARTICLE INFO

Article history:

Received June 11, 2020

Received in revised form November 30, 2020

Accepted December 5, 2020

\section{KEYWORDS:}

Amaranthus tricolor $\mathrm{L}$,

growth,

vitamin C.

salicylic acid,

oxalate content

\begin{abstract}
Red amaranth (Amaranthus tricolor L.) contains phytochemicals that are important for human health, however it also contains oxalate that may cause uric acid problem in human health. This experiment was carried out to evaluate the effect of salicylic acid (SA) on growth, oxalate, chlorophyll, and vitamin $C$ contents in red amaranth. Red amaranth seeds were germinated in a plastic pot containing a mixture of top soil and organic fertilizer. Three week-old seedlings were applied with SA of $0 \mathrm{M}$ (control), $10^{-8}, 1^{-6}, 1^{-4}$ or $10^{-2} \mathrm{M}$. Five replicates were prepared for each treatment. Growth parameters observed were plant height, fresh weight, and dry weight of plant. The Ca-oxalate crystal density was determined by observing stem section under the microscope. Chlorophyll and oxalic acid content were determined by spectrophotometer method, whereas vitamin $C$ content was determined by titration method. The results showed that plant height and root length were tend to decline by $\mathrm{SA}$ application, however $\mathrm{SA}$ of $10^{-6} \mathrm{M}$ significantly increased chlorophyll, carotenoid and vitamin $C$ content. All concentrations of $S A$ applied were able to reduce oxalic acid content and Ca-oxalate crystal density in stem. It can be inferred that application of SA generally enhances nutrient quality of red amaranth.
\end{abstract}

\section{Introduction}

Red amaranth (Amaranthus tricolor L.) is one of vegetables that has been widely cultivated in Indonesia. Amaranth foliage contains high nutritive value and is an excellent source of bio-available iron and vitamin A (Funke 2011). It has been reported by Peter et al. (2014) that in fresh leaves of $A$. cruenthus, $\beta$-carotene, iron and zinc content was $5.75 \pm 0.04,8.47 \pm 0.05$, and $3.18 \pm 0.04 \mathrm{mg} / 100 \mathrm{~g}$, respectively. Amaranth leaves and seeds are good source of protein. According to Andini et al. (2013) the average protein content in leaves of cultivated A. cruentus L. and A. tricolor L. were about $16 \%$. Amaranth is also considered as a drought resistant plant and it can be appraised for future crop that can withstand climate change. However, beside its nutritive contents, amaranth leaves and grain contain oxalate. The presence of oxalate in food decline the availability of calcium and magnesium and for human being it can promote kidney stone development. From analysis of 30 genotypes amaranth's grain, the average concentration

\footnotetext{
* Corresponding Author

E-mail Address: kumala.dewi@ugm.ac.id
}

of oxalate was $229 \mathrm{mg} / 100 \mathrm{~g}$ (Gelinas and Seguin 2017). Another report by Vityakon and Standal (1989) showed that total oxalate content was $91 \mathrm{~g} \mathrm{~kg}^{-1}$ on a dry weight basis in A. gangeticus L. grown in three different soil types and climatic factors. The average content of oxalate in plants is also affected by nitrogen source and the availability of inorganic ions (Libert and Francheschi 1987). Efforts in reducing oxalate content in vegetable are still important to be conducted.

It has been suggested that oxalic acid biosynthesis can be derived from glyoxylate/glycolate, ascorbate, and oxaloacetate (Cai et al. 2015). In spinach, the accumulation of oxalate can be regulated by ammonium and nitrate. Under normal condition, the transcription levels of genes that involved in oxalate biosynthesis, such as SoGLO2, SoGLO3, SoOXACs, SoMLS, SoMDH1, SoMDH2, and $\mathrm{SoMDH}$ were high and it leads to high oxalate concentration (Cai et al. 2018). According to Kostman et al. (2001) the potential precursor of oxalate is ascorbic acid. Another finding by Truffault et al. (2017) reported that through $\left[{ }^{14} \mathrm{C}\right]$ ascorbate labelling in tomato, oxalate, threonate as well asoxalyl threonate, were found as the degradation products of ascorbate. The degradation of ascorbate in plants may occur enzymatically through 
dehydroascorbate or non-enzymatically (Green and Fry 2005). In plants subjected to adverse environmental condition, one of the plant's defense mechanism is through detoxifying reactive oxygen species (ROS) by ascorbate peroxidase, this enzyme converts $\mathrm{H}_{2} \mathrm{O}_{2}$ into $\mathrm{H}_{2} \mathrm{O}$, using ascorbate as a specific electron donor (Caverzan et al. 2012). However, the mechanisms underlying the biosynthesis and breakdown of oxalate in plant are still undetermined. It has been suggested that ascorbate, dehydro ascorbate and total ascorbate can be reduced by application of salicylic acid in pepper plants treated with either UV-A, UV-B or UV-C (Mahdavian 2018). Salicylic acid (SA) is one of plant hormone that has a major role in regulating plant's defense against biotic and abiotic stress (Pye et al. 2013), and affects oxalate oxidase for oxalate compound breakdowns (Maksimov et al. 2015). This study was aimed to evaluate effects of SA on growth, vitamin C and oxalate content in red amaranth.

\section{Materials and Methods}

\subsection{Sample Preparation, Design Experiment and Data Calculation}

This study was conducted in Greenhouse of Faculty of Biology Universitas Gadjah Mada during April to July 2018 and repeated in 2019. Red amaranth seeds were germinated in a plastic pot containing a mixture of top soil and compost fertilizer $(3: 1=\mathrm{v}: \mathrm{v})$. Seedlings were selected and three seedlings were kept growth in each plastic pot. Three weeks old seedlings were then applied with salicylic acid of $0 \mathrm{M}$ (control), $10^{-8}$, $10^{-6}, 10^{-4}$ or $10^{-2} \mathrm{M}$. Two weeks later, root length, plant height, fresh weight and dry weight of shoot and root were measured. Chlorophyll and carotenoid content were determined spectrophotometrically, vitamin C was determined by titration method whereas distribution of crystal oxalate was determined through anatomical observation of stem section. Data were analyzed with One Way ANOVA in 95\% confidence level, and continued by DMRT with $5 \%$ significant level if there is a significant difference between means.

\subsection{Chlorophyll Content Determination}

Two grams of leaves sampel was crushed using a mortar and pestle and extracted in $10 \mathrm{~mL}$ of $80 \%$ acetone. Leaf extract was filtered using a Whatman filter paper and the absorbance of leaf extract was measured with UV-Vis Spectrophotometer at $645 \mathrm{~nm}$ and $663 \mathrm{~nm}$ for chlorophyll content determination. The formula for calculating total chlorophyll content was as follow:

$\begin{gathered}\text { Total chlorophyll } \\ \text { content }(\mathrm{mg} / \mathrm{g})\end{gathered}=\frac{\left(\left(20.2 \times \mathrm{A}_{645}\right)-\left(8.02 \times \mathrm{A}_{663}\right)\right) \times \mathrm{V}}{1000 \times \mathrm{W}}$
Where,
$\mathrm{V}$ : volume of filtrate,
W : leaf fresh weight, and
A : absorbance value of leaf extract (Arnon 1949)

\subsection{Ascorbic Acid Content Determination}

Vitamin C quantification was performed according to the method described by AOAC (1984) and results were expressed as $\mathrm{mg}$ ascorbic acid per 100 grams of leaf fresh weight. Two grams of leaf sample was mashed and diluted with $15 \mathrm{~mL}$ of aquadest. The solution was filtered and diluted into $250 \mathrm{~mL}$ with aquadest and then $50 \mathrm{~mL}$ of filtrate was added with $2 \mathrm{~mL}$ of amylum $1 \%$ in $125 \mathrm{~mL}$ erlenmeyer and titrated with iodine of $0.01 \mathrm{~N}$. The content of ascorbic acid was determined with the following formula:

$$
\text { Ascorbic acid }=\frac{V \text { Iodine } \times \mathrm{N} \text { Iodine } \times 0.88 \times \mathrm{df} \times 100}{\text { sample weight }(\mathrm{g})}
$$

With,

$1 \mathrm{mg}$ iod $0.01 \mathrm{~N}=0.88 \mathrm{mg}$ of ascorbic acid

\subsection{Oxalic Acid Content Determination}

The oxalic acid content was determined according to Fitriani et al. (2016) with modification. Two grams of red amaranth leaves was crushed with a mortar and pestle and then added with $100 \mathrm{~mL}$ aquadest. The extract was heated for 20 minutes and then filtered. The filtrate was diluted with aquadest to $250 \mathrm{~mL}$ and then $50 \mathrm{~mL}$ of solution was taken and added with 1 $\mathrm{mL}$ of $\mathrm{H}_{2} \mathrm{SO}_{4}$. The solution was titrated with $\mathrm{KMnO}_{4}$ until the equivalent point was reached. The formula for calculating oxalic acid content is as follow:

$$
\begin{aligned}
& \text { Oxalic acid normality } \mathrm{V}_{\mathrm{K}} \times \mathrm{N}_{\mathrm{K}}=\mathrm{V}_{\mathrm{O}} \times \mathrm{N}_{\mathrm{O}} \\
& \mathrm{V}_{\mathrm{O}} \times \mathrm{N}_{\mathrm{O}}=\frac{\text { Oxalic acid mass }(\mathrm{mg})}{\mathrm{EW}}
\end{aligned}
$$

$$
\text { Oxalic acid content }(\mathrm{mg} / 100 \mathrm{~g})=\frac{\begin{array}{c}
\text { Oxalic acid } \\
\text { mass }(\mathrm{mg})
\end{array}}{\begin{array}{c}
\text { sample } \\
\text { weight }(\mathrm{g})
\end{array}} \times 10^{2}
$$

Where,

$$
\begin{array}{ll}
\mathrm{V}_{\mathrm{K}} & \text { : Volume of potassium permanganate }(\mathrm{mL}) \\
\mathrm{N}_{\mathrm{K}} & \text { : Normality of potassium permanganate }(\mathrm{N}) \\
\mathrm{V}_{\mathrm{O}} & \text { : Volume of sample }(\mathrm{mL}) \\
\mathrm{N}_{\mathrm{O}} & \text { : Normality of oxalic acid }(\mathrm{N}) \\
\mathrm{EW} & \text { : Equivalent weight of oxalic acid }=63
\end{array}
$$




\subsection{Stem Section and Ca-oxalate Crystal Density Determination}

The stem was free-hand sectioned and the sections was placed in $70 \%$ alcohol and each section was observed under microscope and documented using an optilab. Density of Ca-oxalate crystal was calculated by a formula mentioned by Harijati et al. (2011) as follow:

$$
\text { Density }=\frac{\text { Total of observed crystal }}{\text { View area }\left(\mathrm{mm}^{2}\right)}
$$

\section{Results}

\subsection{Growth of Red Amaranth}

In general, application of SA up to $10^{-4} \mathrm{M}$ through foliar spraying in red amaranth caused a slight reduction on the average of plant height, whereas the highest concentration of SA applied in this research $\left(10^{-2} \mathrm{M}\right)$ inhibitted vegetative growth of red amaranth. Figure 1. illustrates the morphology of control and SA treated amaranth plants. In Figure 2, it can be seen that there was a trend for slight reduction in plant height of those plants treated with SA of $10^{-8} \mathrm{M}, 10^{-6} \mathrm{M}$ or $10^{-4} \mathrm{M}$ and for plants treated with SA of $10^{-2} \mathrm{M}$ the plant height was significantly decreased compared to control. Similar trend was also found for root length.

\subsection{Biomass of Red Amaranth}

From Table 1, it can be seen that SA concentration of $10^{-8} \mathrm{M}, 10^{-6} \mathrm{M}$ or $10^{-4} \mathrm{M}$ did not significantly influence fresh weight of root and shoot. However, the highest concentration of SA $\left(10^{-2} \mathrm{M}\right)$ reduced

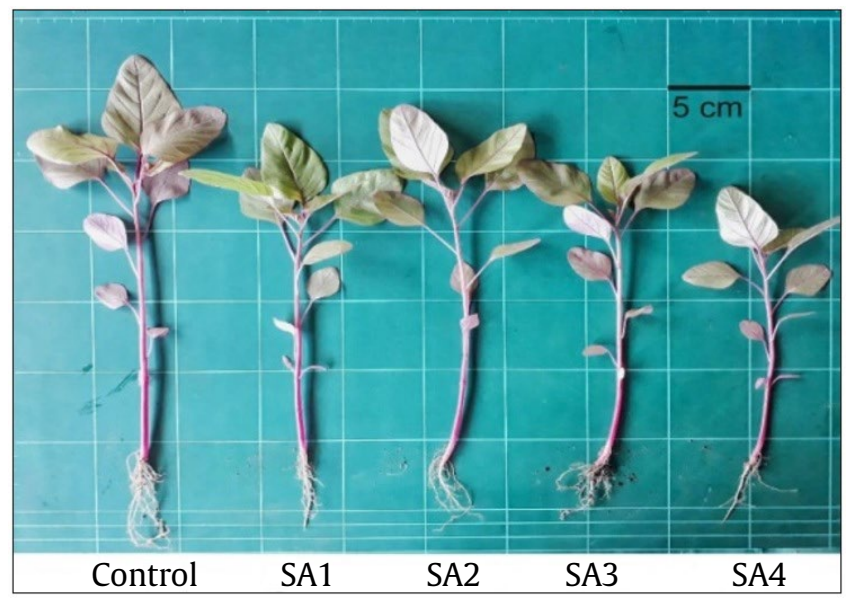

Figure 1. Phenotype of Amaranthus tricolor L. treated with salicylic acid. Note: SA1 = SA $10^{-8} \mathrm{M}, \mathrm{SA} 2=\mathrm{SA} 10^{-6} \mathrm{M}, \mathrm{SA} 3=\mathrm{SA} 10^{-4} \mathrm{M}$, SA4 $=$ SA $10^{-2}$ (Courtesy of $\mathrm{CB}$ Asy Shyfa) significantly red amaranth fresh weight compared to control. Total dry weight of red amaranth treated with SA decreased accordingly to the total fresh weight of shoot and roots in those plants treated with salicylic acid.

\subsection{Chlorophyll Content of Red Amaranth}

The result of chlorophyll determination is presented in Figure 3. It was showed that the highest chlorophyll content was found in plants treated with $10^{-6} \mathrm{MSA}$, however, the chlorophyll content decreased in plants treated with higher concentration of SA.

\subsection{Ascorbic Acid and Oxalate Content of Red Amaranth}

In Table 2, it was found that application of

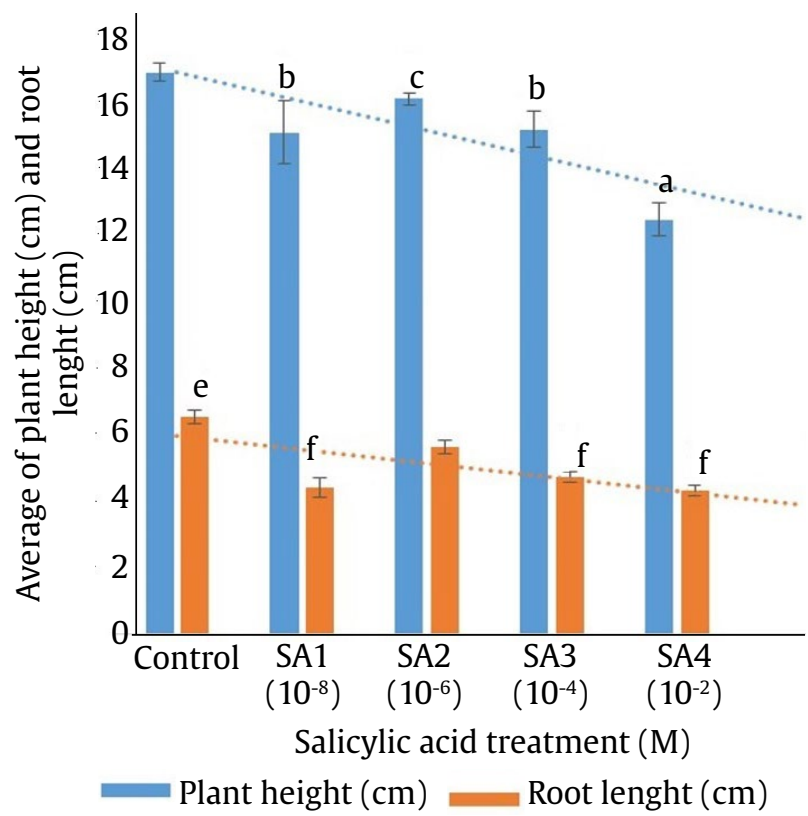

-... Linear (plant height $(\mathrm{cm})) \cdots \cdot$. Linear (root height $(\mathrm{cm})$ ) Figure 2. Effect of salicylic acid on average \pm SE of plant height and root length of Amaranthus

Table 1. Fresh and dry weight of A. tricolor L. treated with salicylic acid

\begin{tabular}{ccc}
\hline $\begin{array}{c}\text { Salicylic acid } \\
\text { treatment } \\
(\mathrm{M})\end{array}$ & $\begin{array}{c}\text { Total of shoot } \\
\text { and root fresh } \\
\text { weight }(\mathrm{g})\end{array}$ & $\begin{array}{c}\text { Total of shoot and } \\
\text { root dry weight }(\mathrm{g})\end{array}$ \\
\hline Control & $2.4 \pm 0.33^{\mathrm{b}}$ & $0.213 \pm 0.026^{\mathrm{c}}$ \\
SA1 $\left(10^{-8}\right)$ & $2.3 \pm 0.33^{\mathrm{b}}$ & $0.150 \pm 0.008^{\mathrm{b}}$ \\
SA2 $\left(10^{-6}\right)$ & $2.1 \pm 0.46^{\mathrm{b}}$ & $0.168 \pm 0.021^{\mathrm{b}}$ \\
SA3 $\left(10^{-4}\right)$ & $2.1 \pm 0.22^{\mathrm{b}}$ & $0.160 \pm 0.022^{\mathrm{b}}$ \\
SA4 $\left(10^{-2}\right)$ & $1.5 \pm 0.33^{\mathrm{a}}$ & $0.110 \pm 0.031^{\mathrm{a}}$ \\
\hline
\end{tabular}

The number followed by the same letter in the same collumn has no significant difference based on DMRT $\alpha=0.05, \mathrm{n}=5$ 
salicylic acid increased the content of ascorbic acid, on the other hand, the content of oxalic acid and the density of Ca-oxalate crystal in stem of red amaranth decreased by application of salicylic acid (Figure 4.).

\section{Discussion}

\subsection{Growth of Red Amaranth}

The results of this experiment showed that both plant height and root length tend to decline by application of SA. The highest concentration of SA applied caused a significant reduction in plant height whereas root length of those plants treated with SA was slightly decline compared to control plant. As a plant hormone, the physiological effect of salicylic acid may different amongst many species and it depends on concentration applied to the plant, frequency of application as well as the physiological age of plants. In many cases salicylic acid was reported to increase growth and yield of plant especially those grown under mild stress such as in Dianthus superbus L. It has been reported that

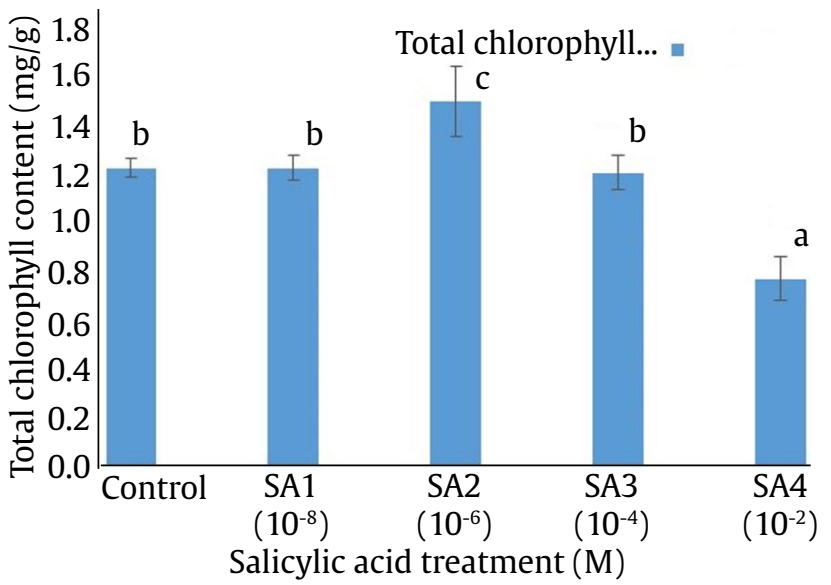

Figure 3. Effect of salicylic acid on chlorophyll content $(\mathrm{mg} / \mathrm{g})$. The same letter above the column showed no significant difference based on DMRT, $\alpha=0.05 \mathrm{n}=5$ under moderate salinity stress, foliar application of SA effectively increased leaf biomass, soluble protein and sugar content, and up regulated the expression of MYB and P5CS in the D. superbus. However, there was no significant difference in plant's physiological responses as well as relevant gene expression between plants treated with or without SA when the plants were subjected to an extreme salt stress $(0.9 \% \mathrm{NaCl})$ (Zheng et al. 2018). Foliar application of SA ( $3 \mathrm{mM}$ ) increased vegetative growth, number of flower and earliness in strawberry (Mohamed et al. 2017). According to (Canakci 2011), SA application of $1.5 \mathrm{mM}$ to Capsicum annuum L. caused a stimulating effect while inhibition of seedling growth was found when SA was applied at higher concentration $(5 \mathrm{mM}$ or $10 \mathrm{mM}$ ). The inhibition of shoot brought by highest SA concentration probably due to the interaction of SA with other hormones such as auxin, or abscisic acid. In Arabidopsis mutants cpr5, cpr6, and snc1 mutants that contain increased endogenous SA levels, the plants possess reduced apical dominance and stunted growth phenotypes and it reminiscent of AUX-deficient or AUX-insensitive mutants. In addition, these SA-accumulating mutants contain lower endogenous levels of free IAA and reduced sensitivity to AUXs compared with wild-type plants (Wang et al. 2007). In cucumber (Cucumis sativus L.) it was reported that SA treatment increased the endogenous content of abscisic acid and this abscisic acid leads to stomatal closure, whereas the endogenous content of auxin and gibberellins were not affected (Hao et al. 2011). It has been reported by Pasternak et al. (2019), that low concentration of SA (below $50 \mu \mathrm{M}$ ) induced adventitious roots and altered architecture of the root apical meristem in Arabidopsis thaliana, whereas high-concentration of SA (greater than $50 \mu \mathrm{M}$ ) inhibited all growth processes in the root. Auxin synthesis and transport are altered in plants subjected to exogenous SA. It was suggested that auxin synthesis might be promoted

Table 2. Oxalate content and Ca-oxalate density in A. tricolor treated with salicylic acid

\begin{tabular}{lccc}
\hline Concentration of SA $(\mathrm{M})$ & Ascorbic acid $(\mathrm{mg} / 100 \mathrm{~g})$ & \multicolumn{2}{c}{ Oxalate content } \\
\cline { 3 - 4 } & & & $\begin{array}{c}\text { Ca-oxlate crystal density } \\
\left.\text { (crystal/mm }{ }^{2}\right)\end{array}$ \\
\hline Control & $0.2751 \pm 0.0739^{\mathrm{a}}$ & $112 \pm 15^{\mathrm{c}}$ & $43.00 \pm 6.63^{\mathrm{d}}$ \\
SA1 $\left(10^{-8}\right)$ & $0.4499 \pm 0.023^{\mathrm{b}}$ & $103 \pm 11^{\mathrm{bc}}$ & $17.75 \pm 2.20^{\mathrm{b}}$ \\
SA2 $\left(10^{-6}\right)$ & $0.5720 \pm 0.120^{\mathrm{b}}$ & $93 \pm 6^{\mathrm{b}}$ & $14.12 \pm 1.42^{\mathrm{b}}$ \\
SA3 $\left(10^{-4}\right)$ & $0.5720 \pm 0.196^{\mathrm{b}}$ & $90 \pm 7^{\mathrm{b}}$ & $11.03 \pm 1.49^{\mathrm{a}}$ \\
SA4 $\left(10^{-2}\right)$ & $0.5257 \pm 0.108^{\mathrm{b}}$ & $66 \pm 4^{\mathrm{a}}$ & $30.59 \pm 1.79^{\mathrm{c}}$ \\
\hline
\end{tabular}

The number followed by the same letter in the same collumn has no significant difference based on DMRT $\alpha=0.05 \mathrm{n}=5$ 


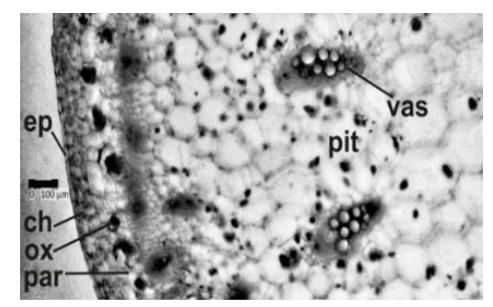

Control

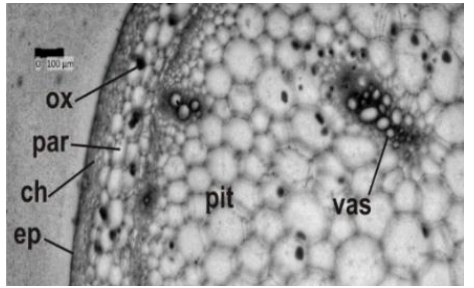

$\mathrm{SA}\left(10^{-8} \mathrm{M}\right)$

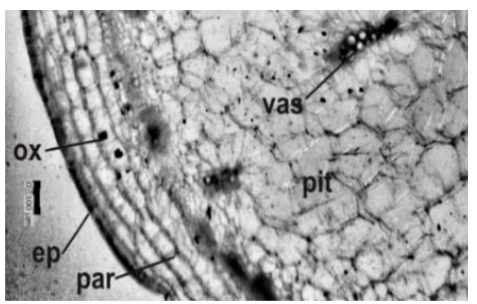

$\mathrm{SA}\left(10^{-4} \mathrm{M}\right)$
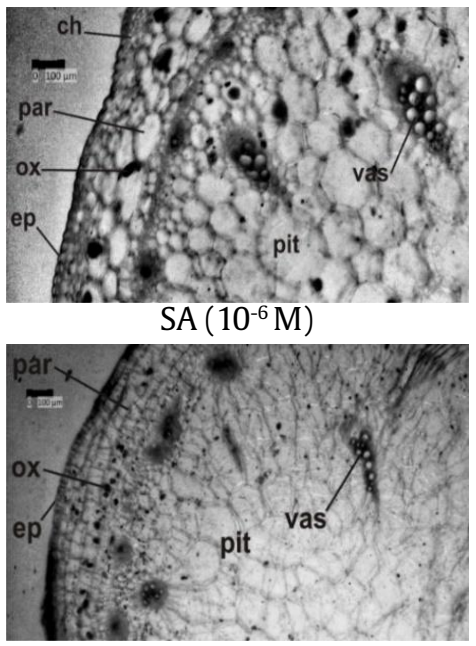

$\mathrm{SA}\left(10^{-2} \mathrm{M}\right)$

Figure 4. Stem anatomical structure of $A$. tricolor treated with salicylic acid. Magnified 4 x 10, Note: ep $=$ Epidermis, ox $=$ Ca-oxalate crystal, $\mathrm{ch}=$ collenchyma, par = parenchyma, pit $=$ pith, vas = vascular bundle, $\mathrm{Bar}=100 \mu \mathrm{M}$ (Courtesy of C.B. Asy Shyfa)

by a wide range of SA concentrations, but the auxin transport was dose dependent on SA concentration. The decline in plant height and root length of red amaranth treated with higher SA possibly associated with the reduction in endogenous auxin and/or inhibition of auxin transport as well as an increased in the endogenous abscisic acid. The mechanism by which high concentration of SA inhibit shoot and root growth in red amaranth still warrant further examination.

\subsection{Biomass of Red Amaranth}

The results presented in Table 1 showed that there was no significant difference in the fresh weight of shoots and roots of red amaranth plants treated with SA up to $10^{-4} \mathrm{M}$ compared to control whereas the highest concentration of SA applied $\left(10^{-2} \mathrm{M}\right)$ reduced the fresh weight of shoots and roots. However, the dry weight of shoots and roots in those plants treated with all concentration of SA were less compared to control. The reduction in the dry weight probably due to the increased content of abscisic acid that caused stomatal closure. When the stomata were closed the transpiration will also decline and consequently the absorption of water by roots will be limited. This condition will reduce cell growth and eventually the biomass. Endogenous hormonal content in Arabidopsis thaliana mutant sid2 having deficiency in SA content has been evaluated by Abreu and Munne-Bosch (2009), and it has been found that the cytokinin content as well as abscisic acid in leaves of that mutant were also low. They suggested that there is a cross-talk between salicylic acid and other phytohormones during plant development. In Arabidopsis, Seo and Park (2010) reported that MYB96 transcription factor acts as a signaling link that integrates $A B A$ and $S A$ signals and regulates a synergistic interaction between the two stress hormones. The synergistic interaction between salicylic acid and abscisic acid was also reported in wheat in which SA increased the endogenous content of abscisic acid as well as $\mathrm{H}_{2} \mathrm{O}_{2}$ (Wang et al. 2018). In Brassica juncea, it has been reported that the dry matter accumulation was significantly enhanced when lower concentrations of SA were sprayed, however, higher concentrations of SA had an inhibitory effect (Fariduddin et al. 2003). It is possible that application of high concentration of SA could increase the endogenous abscisic acid and as a consequence it inhibits growth as well as biomass 
accumulation on red amaranth. The growth stimulation or inhibition by SA is related to change in hormonal status (Shakirova et al. 2003), therefore the complete hormone profile determination in red amaranth treated with different concentration of SA is needed to elucidate the mechanism of SA in increasing or decreasing plant's biomass.

\subsection{Chlorophyll Content of Red Amaranth}

In barley, application of high concentration of SA (1-5 $\mathrm{mM}$ ) reduced photosynthesis rate and RuBisCO activity (Pancheva et al. 1996) and also reduced chlorophyll content in cowpea (rao et al. 1997). In this experiment, application of $10^{-6} \mathrm{M}$ of salicylic acid slightly increased total chlorophyll content of red amaranth. Similar finding has been reported by Khandaker et al. (2011) in which application of $10^{-6} \mathrm{M}$ SA to red amaranth increased chlorophyll content and other biochemical compound such as betacyanin and total polyphenol. Li et al. (1992) suggested that application of SA inhibited the activity of ACC synthase in tomato fruit and it lead to the limitation of ethylene synthesis as well as chlorophyll degradation. It is possible that the slight increase in chlorophyll content of red amaranth treated with $10^{-6} \mathrm{M}$ salicylic acid also due to the reduction of ethylene biosynthesis or through other mechanisms. Highest concentration of SA applied to red amaranth in this experiment $\left(10^{-2} \mathrm{M}\right)$ also reduced chlorophyll content. In barley, high concentration of SA (1-5 mM) reduced photosynthesis rate and RuBisCO activity (Pancheva et al. 1996) and similar finding was also reported in cowpea (Rao et al. 1997). According to Singh and Chaturvedi (2012), the decline in chlorophyll content following higher concentration of SA application probably due to chlorophyll degradation or inhibition of chlorophyll biosynthesis and it depends on species and both internal or external factors. The mechanism by which salicylic acid application increased or decreased chlorophyll content in red amaranth still warrants further examination.

\subsection{Ascorbic Acid and Oxalate Content of Red Amaranth}

The results presented in Table 2. Showed that the content of ascorbic acid increased in red amaranth plants treated with SA. It was suggested that ascorbic acid in plants functions as a protective molecule against reactive oxygen species that are formed from photosynthetic and respiratory processes. In addition, it also plays role as a co-factor for many enzymes. Involved in the cell cycle as well as other mechanisms of plant's cell growth and division (Smirnoff 1996). By feeding the Pistia stratoites with $1-\left[{ }^{14} \mathrm{C}\right]$-ascorbic acid, Kostman et al. (2001) showed that ascorbic acid is the precursor of oxalic acid. In tomato, it has been reported that application of SA $10^{-2} \mathrm{M}$ increased ascorbic acid content compared to control (Javaheri et al. 2012). Similar finding has been shown in Mango stored at $5^{\circ} \mathrm{C}$, in which application of SA increased both enzymatic and non-enzymatic antioxidants including ascorbic acid (Junmatonga et al. 2015). They suggested that SA may prevent the loss of ascorbic acid through inhibition of ascorbic acid oxidase (AAO) activity that breakdown ascorbic acid. The mechanism by which SA treatment increased ascorbic acid content in red amaranth was possibly through the decrease activity of ascorbic acid oxidase but this assumption needs further examination. It has been reported by Debolt et al. (2007) that ascorbic acid is a precursor of oxalic acid biosynthesis in plants. However, the finding in red amaranth argued that ascorbic acid is the main precursor of oxalic acid since the content oxalic acid decreased in those plants having higher ascorbic acid content. According to Cai et al. (2018), the high concentration of oxalate in spinach grown under normal condition was due to the high expression of several genes that involved in oxalate biosynthesis like SoGLO2, SoGLO3, three SoOXACs, SoMLS, SoMDH1, SoMDH2, and SoMDH4. They also suggested that the level of oxalate in plants is controlled by a complex regulatory mechanism and it also depends on plant varieties. Beside ascorbic acid, it was suggested that glyoxylate/glycolate and oxaloacetate could become a precursor of oxalic acid (Cai et al. 2015). Another possibility of oxalate precursor was the oxidative degradation of oxaloacetate which presumably catalyzed by oxaloacetate acetylhydrolase (OXAC) (Chang and Beevers 2007). Further metabolism and molecular examination still need to be carried out to elucidate the main precursor of oxalate found in red amaranth treated with salicylic acid.

It has been reported by Maksimov et al. (2015) that in wheat callus, the activity of oxalate oxidase increased when it was applied with exogenous SA. It was known that oxalate oxidase will breaks down oxalic acid into $\mathrm{CO}_{2}$ and $\mathrm{H}_{2} \mathrm{O}_{2}$ (Walker and Farmiani 2018). In Amaranthus hybridus treated with abscisic acid (ABA), oxalate was not detected in the leaf and it was suggested that there was a rapid breakdown of oxalate into $\mathrm{CO}_{2}$ and $\mathrm{H}_{2} \mathrm{O}_{2}$ by oxalate oxidase (Tooulakou et al. 2016). The red amaranth treated with SA probably also possessed high endogenous $A B A$, thus the level of oxalate decreased in those plants treated with SA. Most 
of the plants produce oxalate endogenously and it has been considered that oxalate plays an important role in calcium regulation (Rahman and Kawamura 2011). The calcium oxalate crystal formed inside the idioblast and it also depends on the membrane, chamber, or secretory products found within the vacuole (Horner and Wagner 1995). Efforts for lowering oxalate accumulation has been carried out such as in transgenic tomato (Solanum lycopersicum) plants expressing an oxalate decarboxylase (OXDC) from the fungus Flammulina velutipes (FvOXDC) specifically in the fruit. This OXCD is an enzyme that catalyze decarboxylative degradation of oxalic acid to form formic acid and carbon dioxide. This transgenic tomato fruit showed up to a $90 \%$ reduction in oxalate content, which correlated with concomitant increases in calcium, iron, and citrate (Chakraborty et al. 2013). However, the explanation about factors which can affect the size or type of calcium oxalate crystal is still limited. A study about calcium oxalate ultrastructure change seems important to be conducted.

The cross section of $A$. tricolor stem treated with SA is shown in Figure 4. It was noted that structure of chollenchyma and parenchyma tissue in red amaranth stem treated with $10^{-4} \mathrm{M}$ or $10^{-2} \mathrm{M}$ SA were slightly expanded compared to control. The collenchyma and parenchyma cell expansion found in those plants treated with SA probably caused by $\mathrm{H}_{2} \mathrm{O}_{2}$ that could be emitted from oxalate breakdowns. According to (Xiong et al. 2015), $\mathrm{H}_{2} \mathrm{O}_{2}$ could cause cell expansion because it affected cell wall structure and hence the collenchyma cells did not form a normal thickening in the cell wall.

\section{Conclusion}

From the results and discussions, it can be inferred that application of $10^{-2} \mathrm{M}$ salicylic acid to red amaranth plants reduced plant height, root length, chlorophyll content, biomass accumulation, oxalic acid, and crystal Ca-oxalate distribution in stem, however, the content of ascorbic acid increased by application of SA. This SA treatment which lowers oxalate content in forms of oxalic acid and calcium oxalate crystal yet increased vitamin $\mathrm{C}$ level in red amaranth seems beneficial in respect of healthy food despite the biomass was reduced by SA application. For obtaining a relatively good performance in biomass and low oxalate level in red amaranth, treatment with SA of $10^{-6} \mathrm{M}$ is recommended since this treatment also increased chlorophyll as well as vitamin C content. Further examination on hormonal and other phytochemical contents, enzymatic activity and expression of various genes involved in oxalate regulation still need to be conducted.

\section{Acknowledgements}

This study was financially supported by Research Grant No. UGM/BI/1671/M/01/05 for Lecturer and students of Faculty of Biology, Universitas Gadjah Mada and RTA (Rekognisi Tugas Akhir). Letter Task No. 3023/ UNI/DITLIT/DIT-LIT.LT/2019.

\section{References}

Abreu ME, Munne-Bosch S. 2009. Salicylic acid deficiency in $N a h G$ transgenic lines and sid2 mutants increases seed yield in the annual plant Arabidopsis thaliana. Journal of Experimental Botany 60:1261-1271. DOI:10.1093/ jxb/ern363

Andini RS et al. 2013. Amaranthus genetic resources in Indonesia: morphological and protein content assessment in comparison with worldwide amaranths. Genetic Resource of Crop Evolution 60:2115-2128. DOI:10.1007/s10722-013-9979-y

[AOAC] Association of Official Analytical Chemists. 1984. Official Method of Analysis. Washington DC: Association of Official Analytical Chemists.

Arnon DI. 1949. Copper enzymes in isolated chloroplasts, polyphenol oxidase in Beta vulgaris. Plant Physiology 2:1-15. DOI:10.1104/pp.24.1.1

Cai XF et al. 2015. The oxalic acid in plants: biosynthesis, degradation and its accumulation regulation (Review in Chinese). Journal of Plant Physiology 51:267-272. DOI:10.3390/molecules23061286

Cai XF et al. 2018. Expression analysis of oxalate metabolic pathway genes reveals oxalate regulation patterns in spinach. Molecules 23:1286-1301. DOI:10.3390/ molecules23061286

Canakci S. 2011. Effects of salicylic acid on growth, biochemical constituents in pepper (Capsicum annuum 1.) seedlings. Pakistan Journal of Biological Sciences 14:300-304. DOI:10.3923/pjbs.2011.300.304

Caverzan AP et al. 2012. Plant responses to stresses: role of ascorbate peroxidase in the antioxidant protection. Genetics and Molecular Biology 35:1011-1019. DOI:10.1590/S1415-47572012000600016.

Chakraborty NR et al. 2013. Reduction of oxalate levels in tomato fruit and consequent metabolic remodeling following overexpression of a fungal oxalate decarboxylase. Plant Physiology. 162:364-378. DOI:10.1104/pp.112.209197

Chang CC, Beevers H. 2007. Biogenesis of oxalate in plant tissues. Plant Physiology 43:1821-1828. DOI:10.1104/ pp.43.11.1821

Debolt S et al. 2007. Ascorbate as a biosynthetic precursor in plants. Annals of Botany 99:3-8. DOI:10.1093/aob/ mcl236

Fariduddin Q et al. 2003. Salicylic acid influences net photosynthetic rate, carboxylation efficiency, nitrate reductase activity, and seed yield in Brassica juncea. Photosynthetica. 41:281-284. DOI:10.1023/ B:PHOT.0000011962.05991.6c

Fitriani Het al. 2016. Kandungan asam oksalat sayur bayam. Medical Laboratory Technology Journal 2:51-55. 
Funke OM. 2011. Evaluation of nutrient contents of amaranth leaves prepared using different cooking methods. Food and Nutrition Sciences 2:249-252. DOI:10.4236/ fns.2011.24035

Gelinas B, Seguin P. 2017. Oxalate in grain amaranth. Journal of Agricultural and Food Chemistry 55:4789-4794. DOI:10.1021/jf070384d

Green MA, Fry SC. 2005. Vitamin C degradation in plant cells via enzymatic hydrolysis of 4-O-oxalyl-L-threonate. Nature 433:83-7. DOI:10.1038/nature03172

Hao JH et al. 2011. Salicylic acid induces stomatal closure by modulating endogenous hormone levels in cucumber cotyledons. Russian Journal of Plant Physiology 5:906913. DOI:10.1134/S1021443711050098

Harijati N et al. 2011. Pengaruh pemberian kalsium terhadap ukuran dan kerapatan kristal kalsium oksalat pada porang (Amorpophallus muelleri Blume). Jurnal Pembangunan dan Alam Lestari 1:72-139.

Horner HT, Wagner BL. 1995. Calcium oxalate formation in higher plants. In: Khan SR (Eds.). Calcium Oxalate in Biological System. Boca Raton: CRC PRESS. pp. 53-70.

Li N et al. 1992. Accumulation of wound-inducible ACC synthase transcript in tomato fruit is inhibited by salicylic acid and polyamines. Plant Molecular Biology 18:477-487. DOI:10.1007/BF00040664.

Javaheri M et al. 2012. Effects of salicylic acid on yield and quality characters of tomato fruit (Lycopersicum esculentum Mill.). International Journal of Agriculture and Crop Sciences 4:1184-1187.

Junmatonga CB et al. 2015. Cold storage in salicylic acid increases enzymatic and non-enzymatic antioxidants of Nam Dok Mai No. 4 mango fruit. Science Asia 41:1221. DOI:10.2306/scienceasia1513-1874.2015.41.012

Khandaker L et al. 2011. Foliar application of salicylic acid improved the growth, yield and leaf's bioactive compounds in red amaranth (Amaranthus tricolor L.). Vegetable Crops Research Bulletin 74:77-86. DOI:10.2478/v10032-011-0006-6

Kostman TA et al. 2001. Biosynthesis of l-ascorbic acid and conversion of carbons 1 and 2 of l-ascorbic acid to oxalic acid occurs within individual calcium oxalate crystal idioblasts. Plant Physiology 125:634-640. DOI:10.1104/pp.125.2.634

Libert B, Francheschi VR. 1987. Oxalate in crop plants. Journal of Agriculture and Food Chemistry 35:926-938. DOI:10.1021/jf00078a019

Mahdavian K. 2018. Effect of salicylic acid spray on leaf ascorbate, proline and quercetin content in ultraviolet stressed Pepper seedlings. Journal of Plant Process and Function 6:55-61.

Maksimov IV et al. 2015. Changes in the phytohormone levels in wheat calli as affected by salicylic acid and infection with Tilletia caries, a bunt pathogenic agent. Russian Journal of Plant Physiol. 51:228-233. DOI:10.1023/B:RUPP.0000019219.83823.49

Mohamed RA et al. 2017. Salicylic acid effects on growth, yield, and fruit quality of strawberry cultivars.Journal of Medicinally Active Plants 6:1-11.

Pancheva TV et al. 1996. Effects of salicylic acid on growth and photosynthesis in barley plants. Journal of Plant Physiology. 149:57-63. DOI:10.1016/S01761617(96)80173-8

Pasternak A et al. 2019. Salicylic acid affects root meristem patterning via auxin distribution in a concentrationdependent manner. Plant Physiology 180:1725-1739. DOI:10.1104/pp.19.00130
Peter C et al. 2014. Retention of B-Carotene, Iron and Zinc in solar dried amaranth leaves in Kajiado County, Kenya. IJSBAR 13:329-338.

Pye MF et al. 2013. Induced resistance in tomato by sar activators during predisposing salinity stress. Frontiers Research 4:82-91. DOI:10.3389/fpls.2013.00116

Rahman MM, Kawamura O. 2011. Oxalate accumulation in forage plants: some agronomic, climatic and genetic aspects. Asian-Australian Journal of Animal Science 24:439-448. DOI:10.5713/ajas.2011.10208

Rao MV et al. 1997. Influence of salicylic acid on $\mathrm{H}_{2} \mathrm{O}_{2}$ production, oxidative stress, and $\mathrm{H}_{2} \mathrm{O}_{2}$-metabolizing enzymes. Plant Physiology 115:137-149. DOI:10.1104/ pp.115.1.137

Seo PJ, Park CM. 2010. MYB96-mediated abscisic acid signals induce pathogen resistance response by promoting salicylic acid biosynthesis in Arabidopsis. New Phytologist 186:471-483. DOI:10.1111/j.14698137.2010.03183.x

Shakirova FM et al. 2003. Changes in the hormonal status of wheat seedlings induced by salicylic acid and salinity. Plant Science 164:317-322. DOI:10.1016/ S0168-9452(02)00415-6

Singh PK, Chaturvedi VK. 2012. Effects of salicylic acid on seedling growth and nitrogen use efficiency in cucumber (Cucumis sativus L.). Plant Biosystems-An International Journal Dealing with all Aspects of Plant Biology 146:302-308. DOI:10.1080/11263504.2011.6 02991

Smirnoff N. 1996. The function and metabolism of ascorbic acid in plants. Annals of Botany 78:661-669. DOI:10.1006/anbo.1996.0175

Tooulakou GA et al. 2016. Alarm photosynthesis: calcium

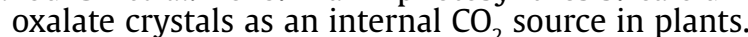
Plant Physiology 171:2577-2585. DOI:10.1104/ pp.16.00111

Truffault V et al. 2017. Ascorbate degradation in tomato leads to accumulation of oxalate, threonate and oxalyl threonate. The Plant Journal 89:996-1008. DOI:10.1111/tpj.13439

Vityakon P, Standal BR. 1989. Oxalate in vegetable amaranth (Amaranthus gangeticus): forms, contents, and their possible implications for human health. Journal of the Science of Food and Agriculture 48:469-474. DOI:10.1002/jsfa.2740480409

Walker RP, Famiani F. 2018. Organic acid in fruits: metabolism, function and content. Horticultural Reviews 45:393430. DOI:10.1002/9781119431077.ch8

Wang DKet al. 2007. Salicylic acid inhibits pathogen growth in plants through repression of the auxin signaling pathway. Current Biology 17:1784-1790. DOI:10.1016/j. cub.2007.09.025

Wang $\mathrm{W}$ et al. 2018. Hydrogen peroxide and abscisic acid mediate salicylic acid-induced freezing tolerance in wheat. Frontiers in Plant Science 9:1137-1150. DOI: $10.3389 /$ fpls

Xiong J et al. 2015. Novel roles of hydrogen peroxide $\left(\mathrm{H}_{2} \mathrm{O}_{2}\right)$ in regulating pectin synthesis and demethylesterification in the cell wall of rice (Oryza sativa) root tips. New Phytologist 206:118-126. DOI:10.1111/nph.13285

Zheng J et al. 2018. Salicylic acid promotes plant growth and salt-related gene expression in Dianthus superbus L. (Caryophyllaceae) grown under different salt stress conditions. Physiologycal Molecular Biology of Plants. 24:231-238. DOI:10.1007/s12298-017-0496-X 